\title{
Toxicity of Rotenone -Yielding Plant Extracts on Fish Fry and Selected Predatory Aquatic Organisms \\ Adebayo IA* and Akin-Obasola BJ
}

Department of Fisheries and Aquaculture Management, Faculty of Agricultural Sciences, Ekiti State University, Ado Ekiti, Ekiti State, Nigeria

\begin{abstract}
Fish fry raised directly in earthen ponds grow faster and healthier but often threatened by a wide range of predatory aquatic organisms which lead to a decline in population at harvest. This study examined the toxicity of rotenone-yielding plant root extracts of Tephrosia bractiolata and Lonchocarpus sericeus on four predatory aquatic organisms namely: Water tigers $\left(\mathrm{W}_{\mathrm{t}}\right)$, Tadpoles $\left(\mathrm{T}_{\mathrm{p}}\right)$, young Crabs $\left(\mathrm{Y}_{\mathrm{c}}\right)$ and Nymph stage of Dragon fly $\left(\mathrm{N}_{\mathrm{d}}\right)$. Using the 96 hours bioassay test to determine acute toxicity for each plant extract, the lethal concentrations ( $\mathrm{LC}_{50}$ ) for $T$. bractiolata and $L$. sericeus were $7 \mathrm{~g}$ and $25 \mathrm{~g} / 70 \mathrm{~L}$ of water respectively for the test organisms. The aquatic organisms were subjected to four test concentrations $(0,6,8$ and $10 \mathrm{~g} / 70 \mathrm{~L})$ for $T$. bractiolata and $(0,20,30$ and 35 $\mathrm{g} / 70 \mathrm{~L})$ for $L$. sericeus respectively in three replicates. Residual effect of the rotenone extract on a week old fry of Clarias gariepinus as non -target organism was determined a week after termination of the first experiment. Results indicated that $T$. bractiolata at lower dose $(\leq 10 \mathrm{~g} / 70 \mathrm{~L})$ was more toxic to the predatory organisms compared to L. sericeus $(\leq 35 \mathrm{~g} / 70 \mathrm{~L})$. As concentrations of root extract increased, water quality parameters such as Dissolved Oxygen (DO), pH and turbidity (transparency) were negatively affected. There was no mortality of fish fry at different doses (6-10 g/70L) of $T$. bractiolata after a week of termination of experiment, while mortality of fish fry was recorded at higher doses ( $30-35 \mathrm{~g} / 70 \mathrm{~L})$ of $L$. sericeus, after a week termination of experiment, showing longer residual effect of $L$. sericeus on fish. In combating aquatic predators in nursery ponds, $T$. bractiolata has higher potency in killing predators at lower doses compared to $L$. sericeus with both plant extracts having minimal residual effect on fish and water quality parameters.
\end{abstract}

Keywords: Rotenone-yielding plants; Toxicity; Root extracts; Aquatic predators; Fish fry

\section{Introduction}

The effective practice of raising fish fry in earthen ponds is yet to be fully achieved. This is attributed to predatory activities of aquatic insects and amphibians arising from improper de-sitting, poor fencing and from water source(s). Predatory organism is a term used to describe organism that attack intended culture fish especially in the fry and juvenile stages. According to Ernest Hodgson [1], predatory aquatic organisms utilize fauna and flora resources available in the water for nourishment, growth, and shelter, thus inhibiting growth of the culture species. The use of rotenone - yielding plants extract aimed at curbing unnecessary aquatic organisms in a pond before stocking became necessary due to its lower residual effect on fish [2].

Rotenone is a colourless and odourless chemical used as a broadspectrum pesticide. It occurs naturally in the stem, roots and sometimes sap of plants which mostly belongs to the legume family [3]. All aquatic organisms are sensitive to rotenone but some are more resistant than others. The study of the potency of rotenone is done by determining the median lethal concentration $\left(\mathrm{LC}_{50}\right)$ values and the impact on the behavior of the aquatic organisms. The Rotenone yielding plants used in this study were Tephrosia bractiolata and Lonchocarpus sericeus. They are leguminous shrubby plants and herbs with enough toxic rotenoids that is highly unselective as it kills both target and nontarget organisms. But the residual effect is harmless to fish after some weeks of application in pond bottom. The root of these plants is the source of the valuable pesticide, rotenone [4]. Control of predatory aquatic organisms is of great importance to fish breeders. Therefore, the objective of the study was to test the toxicity of the plant extracts on the test organisms as well as their effects on physico-chemical parameters of water.

\section{Materials and Methods}

\section{Collection of the test organisms}

Young Crabs $\left(\mathrm{Y}_{\mathrm{c}}\right)$, Tadpoles $\left(\mathrm{T}_{\mathrm{p}}\right)$, Water tigers $\left(\mathrm{W}_{\mathrm{t}}\right)$, and Nymph stage of dragon fly $\left(\mathrm{N}_{\mathrm{d}}\right)$ were collected from the bottom of nursery earthen ponds in the Faculty of Agricultural Sciences Fish farm. They were the endemic predatory aquatic organisms in the ponds area. Selected ponds were carefully drained in order to collect the desired test organisms alive [5-7]. The organisms were immediately sorted into equal size to avoid predation and ensured unbiased reaction to rotenone treatment. Twenty pieces (each) of these organisms were introduced into fresh water in glass tanks $(70 \times 45 \times 40 \mathrm{~cm}) /$ each at 70L of its capacity and replicated thrice. Acclimatization period was two days without drug administration.

\section{Collection of fish samples}

Twenty pieces of a week old fry of Clarias gariepinus hatched within the Faculty of Agricultural Sciences fish hatchery were stocked in glass tanks $(70 \times 45 \times 40 \mathrm{~cm}) /$ each containing fresh water $(70 \mathrm{~L}$ of its capacity) in three replicates. This second experiment on non -target organism (fish) was a continuation of first experiment after a week

*Corresponding author: Adebayo IA, Department of Fisheries and Aquaculture Management, Faculty of Agricultural Sciences, Ekiti State University, Ado Ekiti, Ekiti State, Nigeria, Tel: +234 803583 5; E-mail: dayadeisrael@yahoo.com isreal.adebayo@eksu.edu.ng

Received May 26, 2016; Accepted August 29, 2016; Published August 31, 2016

Citation: Adebayo IA, Akin-Obasola BJ (2016) Toxicity of Rotenone -Yielding Plant Extracts on Fish Fry and Selected Predatory Aquatic Organisms. J Aquac Res Development 7: 443. doi: 10.4172/2155-9546.1000443

Copyright: (c) 2016 Adebayo IA, et al. This is an open-access article distributed under the terms of the Creative Commons Attribution License, which permits unrestricted use, distribution, and reproduction in any medium, provided the original author and source are credited. 
Citation: Adebayo IA, Akin-Obasola BJ (2016) Toxicity of Rotenone -Yielding Plant Extracts on Fish Fry and Selected Predatory Aquatic Organisms. J Aquac Res Development 7: 443. doi: 10.4172/2155-9546.1000443

Page 2 of 5

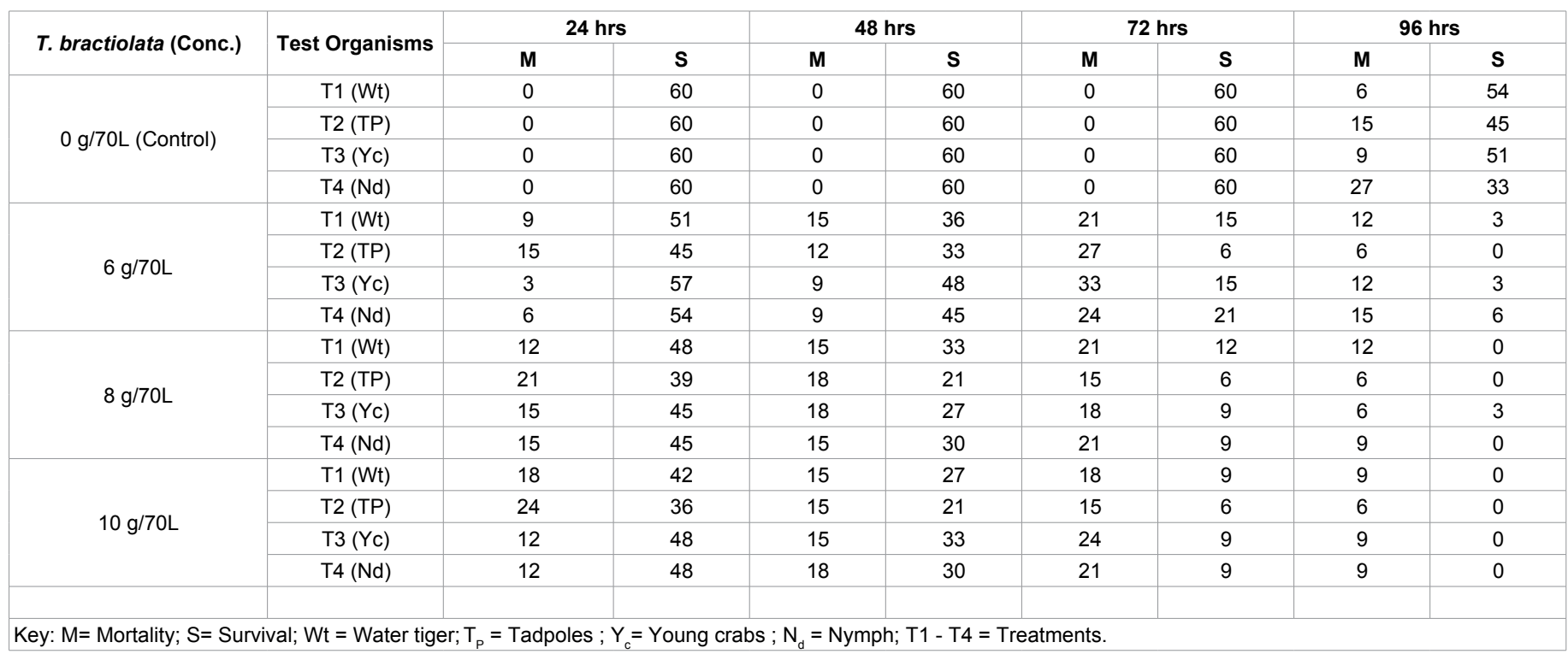

Table 1: Mortality and survival of aquatic predatory organisms at different concentrations of T. bractiolata.

\begin{tabular}{|c|c|c|c|c|c|c|c|c|c|}
\hline \multirow{2}{*}{ Trts } & \multicolumn{3}{|c|}{$\mathrm{pH}$} & \multicolumn{3}{|c|}{ Temp $\left({ }^{\circ} \mathrm{C}\right)$} & \multicolumn{3}{|c|}{$\mathrm{DO}$ (mg/L) } \\
\hline & Before & During & After & Before & During & After & Before & During & After \\
\hline $0 \mathrm{~g} / 70 \mathrm{~L}$ & $7.20 \pm 0.01^{a}$ & $7.20 \pm 0.02^{\mathrm{a}}$ & $7.20 \pm 0.00^{\mathrm{a}}$ & $27.20 \pm 0.02^{a}$ & $26.20 \pm 0.01^{a}$ & $25.91 \pm 0.00^{\mathrm{a}}$ & $5.40 \pm 0.00^{a}$ & $5.40 \pm 0.02^{a}$ & $5.40 \pm 0.02^{a}$ \\
\hline $6 \mathrm{~g} / 70 \mathrm{~L}$ & $7.30 \pm 0.03^{a}$ & $6.75 \pm 0.01^{a}$ & $6.42 \pm 0.02^{b}$ & $27.22 \pm 0.01^{a}$ & $24.75 \pm 0.02^{b}$ & $25.07 \pm 0.01^{a}$ & $5.40 \pm 0.00^{a}$ & $4.25 \pm 0.01^{b}$ & $4.20 \pm 0.01^{b}$ \\
\hline $8 \mathrm{~g} / 70 \mathrm{~L}$ & $7.20 \pm 0.02^{\mathrm{a}}$ & $5.63 \pm 0.03^{b}$ & $6.50 \pm 0.01^{b}$ & $27.30 \pm 0.02^{a}$ & $24.33 \pm 0.03^{b}$ & $25.03 \pm 0.02^{a}$ & $4.42 \pm 0.01^{b}$ & $3.50 \pm 0.01^{c}$ & $3.20 \pm 0.01^{c}$ \\
\hline $10 \mathrm{~g} / 70 \mathrm{~L}$ & $7.25 \pm 0.01^{a}$ & $5.42 \pm 0.01^{b}$ & $6.60 \pm 0.03_{b}$ & $27.20 \pm 0.00^{a}$ & $24.11 \pm 0.02^{\mathrm{b}}$ & $26.00 \pm 0.01^{a}$ & $4.40 \pm 0.02^{b}$ & $3.70 \pm 0.02^{c}$ & $3.20 \pm 0.02^{c}$ \\
\hline
\end{tabular}

Table 2: Mean values of water quality parameters before, during and after the introduction of $T$. bractiolata in experimental tanks.

termination with predatory aquatic organisms, to establish the residual effect of rotenone- yielding root extracts on the young fish [8-11]. The fish fry were allowed to acclimatize for two days without food.

\section{Source and collection of experimental plant extracts}

The plant root extracts used were Tephrosia bractiolata and Lonchocarpus sericeus. They were collected from different locations in IKere-Ekiti, Ekiti state, Nigeria where these plants were endemic. The roots of the plants were collected, and after washing, crushed and further processed by sun -drying and made into powdery state. The potency of the root extracts were tested in the Laboratory using the methods of Organization for Economic Cooperation and Development (OECD) standard guidelines for testing chemicals [12] before usage.

\section{Determination of rotenone from the root extracts}

Method of quantifying rotenone concentrations using high performance liquid chromatography (HPLC) of [13-15] was employed. The analysis procedures involved more sample preparation at concentration as low as $5 \mu \mathrm{g} / \mathrm{L}$.

\section{Range finding test}

After acclimatization of the test organisms, lethal concentrations $\left(\mathrm{LC}_{50}\right)$ for the plant root -extracts were determined. The lethal concentrations $\left(\mathrm{LC}_{50}\right)$ for $T$. bractiolata and L. sericeus were $7 \mathrm{~g}$ and $25 \mathrm{~g} / \mathrm{L}$ respectively (Tables 1 and 2). It is a preliminary test done with the intention of knowing the lethal level with predicted environmental effects [16,17]. The final test concentrations were placed at four testing regimes per root extract at the rate of $(0,6,8$ and $10 \mathrm{~g} / \mathrm{L})$ for $T$. bractiolata and $(0,20,30$ and $35 \mathrm{~g} / \mathrm{L})$ for L. sericeus respectively.

\section{Experimental setup}

Twenty four Glass Aquaria Tanks of size $(70 \times 45 \times 40 \mathrm{~cm}) /$ each that contained $70 \mathrm{~L}$ of freshwater were arranged in three replicates in completely randomized design for both $T$. bractiolata $(0,6,8$ and 10 $\mathrm{g} / \mathrm{L})[18,19]$ and $L$. sericeus $(0,20,30$ and $35 \mathrm{~g} / \mathrm{L})$ doses respectively for the acute toxicity test. The aquatic organisms in the four treatments for each root extracts were Water tiger, Tadpoles, young Crabs and Nymph of dragon fly. Each test concentration (treatment) contains an equal number of aquatic test organisms. This followed the 96 hours acute toxicity test on aquatic predatory organisms (Table 3). Observable effects such as behavioral responses and mortality were recorded at $24 \mathrm{hrs}, 48 \mathrm{hrs}, 72 \mathrm{hrs}$ and $96 \mathrm{hrs}$ respectively [20,21] (Table 4). The test concentrations were selected based on Observable Effect of Concentration (OEC) and the rate of mortality.

\section{Water quality}

The physico-chemical parameters of the experimental media such as $\mathrm{pH}$, temperature, and dissolved oxygen were determined before and after the experiment using appropriate methods.

\section{Statistical analysis}

Data collected from the experiment were subjected to a one-way analysis of variance (ANOVA) and the statistical differences were identified using the Duncan multiple range test [22].

\section{Results}

\section{General effects}

Prior to the introduction of varying concentrations of root extracts 
Citation: Adebayo IA, Akin-Obasola BJ (2016) Toxicity of Rotenone -Yielding Plant Extracts on Fish Fry and Selected Predatory Aquatic Organisms. J Aquac Res Development 7: 443. doi: 10.4172/2155-9546.1000443

Page 3 of 5

\begin{tabular}{|c|c|c|c|c|c|c|c|c|c|}
\hline \multirow{2}{*}{ L. sericeus (Conc.) } & \multirow{2}{*}{ Test Organisms } & \multicolumn{2}{|c|}{$24 \mathrm{hrs}$} & \multicolumn{2}{|c|}{$48 \mathrm{hrs}$} & \multicolumn{2}{|c|}{$72 \mathrm{hrs}$} & \multicolumn{2}{|c|}{$96 \mathrm{hrs}$} \\
\hline & & $\mathbf{M}$ & $S$ & M & $\mathbf{S}$ & M & $\mathbf{S}$ & M & $\mathbf{s}$ \\
\hline \multirow{4}{*}{$0 \mathrm{~g} / 70 \mathrm{~L}$ (Control) } & $\mathrm{T}_{1}(\mathrm{Wt})$ & 0 & 60 & 0 & 60 & 0 & 60 & 6 & 54 \\
\hline & $T_{2}\left(T_{p}\right)$ & 0 & 60 & 0 & 60 & 0 & 60 & 15 & 45 \\
\hline & $\mathrm{T}_{3}\left(\mathrm{Y}_{\mathrm{c}}\right)$ & 0 & 60 & 0 & 60 & 0 & 60 & 3 & 57 \\
\hline & $\mathrm{T}_{4}\left(\mathrm{~N}_{\mathrm{d}}\right)$ & 0 & 60 & 0 & 60 & 0 & 60 & 9 & 51 \\
\hline \multirow{4}{*}{$20 \mathrm{~g} / 70 \mathrm{~L}$} & $\mathrm{~T}_{1}(\mathrm{Wt})$ & 9 & 51 & 15 & 36 & 21 & 15 & 6 & 9 \\
\hline & $T_{2}\left(T_{p}\right)$ & 15 & 45 & 12 & 33 & 27 & 6 & 6 & 0 \\
\hline & $\mathrm{T}_{3}\left(\mathrm{Y}_{\mathrm{c}}\right)$ & 3 & 57 & 9 & 48 & 33 & 15 & 6 & 9 \\
\hline & $\mathrm{T}_{4}\left(\mathrm{~N}_{\mathrm{d}}\right)$ & 6 & 54 & 9 & 45 & 24 & 21 & 15 & 6 \\
\hline \multirow{4}{*}{$30 \mathrm{~g} / 70 \mathrm{~L}$} & $\mathrm{~T}_{1}(\mathrm{Wt})$ & 12 & 48 & 15 & 33 & 21 & 9 & 9 & 0 \\
\hline & $\mathrm{T}_{2}\left(\mathrm{~T}_{\mathrm{p}}\right)$ & 21 & 39 & 18 & 21 & 15 & 6 & 6 & 0 \\
\hline & $\mathrm{T}_{3}\left(\mathrm{Y}_{\mathrm{c}}\right)$ & 15 & 45 & 18 & 27 & 12 & 15 & 12 & 3 \\
\hline & $\mathrm{T}_{4}\left(\mathrm{~N}_{\mathrm{d}}\right)$ & 15 & 45 & 15 & 30 & 21 & 9 & 9 & 0 \\
\hline \multirow{4}{*}{$35 \mathrm{~g} / 70 \mathrm{~L}$} & $\mathrm{~T}_{1}(\mathrm{Wt})$ & 18 & 42 & 15 & 27 & 18 & 9 & 9 & 0 \\
\hline & $T_{2}\left(T_{p}\right)$ & 24 & 36 & 15 & 21 & 15 & 6 & 6 & 0 \\
\hline & $\mathrm{T}_{3}\left(\mathrm{Y}_{\mathrm{c}}\right)$ & 12 & 48 & 15 & 33 & 24 & 9 & 9 & 0 \\
\hline & $\mathrm{T}_{4}\left(\mathrm{~N}_{\mathrm{d}}\right)$ & 12 & 48 & 18 & 30 & 21 & 9 & 9 & 0 \\
\hline
\end{tabular}

Table 3: Mortality and survival of aquatic predatory organisms at different concentrations of $L$. sericeus.

\begin{tabular}{|c|c|c|c|c|c|c|c|c|c|}
\hline \multirow{2}{*}{ Trts } & \multicolumn{3}{|c|}{$\mathrm{pH}$} & \multicolumn{3}{|c|}{ Temp $\left({ }^{\circ} \mathrm{C}\right)$} & \multicolumn{3}{|c|}{ DO (mg/L) } \\
\hline & Before & During & After & Before & During & After & Before & During & After \\
\hline $0 \mathrm{~g} / 70 \mathrm{~L}$ & $7.20 \pm 0.03^{a}$ & $7.20 \pm 0.02^{\mathrm{a}}$ & $7.20 \pm 0.02^{a}$ & $27.10 \pm 0.02^{a}$ & $26.20 \pm 0.04^{a}$ & $25.15 \pm 0.02^{a}$ & $5.40 \pm 0.01^{a}$ & $5.20 \pm 0.02^{a}$ & $5.10 \pm 0.01^{a}$ \\
\hline $20 \mathrm{~g} / 70 \mathrm{~L}$ & $7.30 \pm 0.01^{a}$ & $6.15 \pm 0.00^{b}$ & $6.02 \pm 0.00^{b}$ & $27.12 \pm 0.02^{a}$ & $25.15 \pm 0.02^{\mathrm{b}}$ & $25.07 \pm 0.01^{a}$ & $5.40 \pm 0.02^{\mathrm{a}}$ & $3.20 \pm 0.01^{b}$ & $3.56 \pm 0.02^{b}$ \\
\hline $30 \mathrm{~g} / 70 \mathrm{~L}$ & $7.20 \pm 0.03^{a}$ & $6.10 \pm 0.01^{b}$ & $6.00 \pm 0.01^{b}$ & $27.20 \pm 0.02^{a}$ & $25.30 \pm 0.01^{b}$ & $25.30 \pm 0.03^{a}$ & $5.42 \pm 0.01^{\mathrm{a}}$ & $3.50 \pm 0.01^{b}$ & $3.50 \pm 0.01^{b}$ \\
\hline $35 \mathrm{~g} / 70 \mathrm{~L}$ & $7.30 \pm 0.02^{\mathrm{a}}$ & $6.05 \pm 0.02^{b}$ & $5.60 \pm 0.01^{c}$ & $27.10 \pm 0.02^{a}$ & $25.10 \pm 0.05^{b}$ & $25.10 \pm 0.00^{\mathrm{a}}$ & $5.40 \pm 0.03^{\mathrm{a}}$ & $2.90 \pm 0.03^{c}$ & $2.03 \pm 0.01^{\mathrm{c}}$ \\
\hline
\end{tabular}

Table 4: Mean values of water quality parameters before, during and after the introduction of $L$. sericeus in experimental tanks.

\begin{tabular}{|c|c|c|c|c|c|c|c|c|c|}
\hline \multirow{2}{*}{ Plant Extracts } & \multirow{2}{*}{ Diff. Concs. } & \multicolumn{2}{|c|}{$24 \mathrm{hrs}$} & \multicolumn{2}{|c|}{$48 \mathrm{hrs}$} & \multicolumn{2}{|c|}{$72 \mathrm{hrs}$} & \multicolumn{2}{|c|}{$96 \mathrm{hrs}$} \\
\hline & & M & $\mathbf{S}$ & M & $\mathbf{S}$ & M & $\mathbf{S}$ & M & $\mathbf{S}$ \\
\hline \multirow{4}{*}{ T. bractiolata } & $0 \mathrm{~g} / 70 \mathrm{~L}$ & 0 & 60 & 0 & 60 & 0 & 60 & 0 & 60 \\
\hline & $6 \mathrm{~g} / 70 \mathrm{~L}$ & 6 & 54 & 3 & 51 & 0 & 51 & 0 & 51 \\
\hline & $8 \mathrm{~g} / 70 \mathrm{~L}$ & 6 & 54 & 0 & 54 & 0 & 54 & 0 & 54 \\
\hline & $10 \mathrm{~g} / 70 \mathrm{~L}$ & 15 & 45 & 3 & 42 & 0 & 42 & 0 & 42 \\
\hline \multirow{3}{*}{ L. sericeus } & $20 \mathrm{~g} / 70 \mathrm{~L}$ & 6 & 54 & 0 & 54 & 0 & 54 & 0 & 54 \\
\hline & $30 \mathrm{~g} / 70 \mathrm{~L}$ & 15 & 45 & 0 & 45 & 3 & 42 & 0 & 42 \\
\hline & $35 \mathrm{~g} / 70 \mathrm{~L}$ & 24 & 36 & 0 & 36 & 0 & 36 & 0 & 36 \\
\hline
\end{tabular}

Key: $M=$ Mortality, $S=$ Survival, $W_{t}=$ Water tiger, $T_{P}=$ Tadpoles, $Y_{c}=$ Young crabs, $N_{d}=$ Nymph; $T 1-T 4$ (Treatments)

Table 5: Residual effects of $T$. bractiolata and $L$. sericeus on fish fry after a week of application in water.

\begin{tabular}{|c|c|c|c|c|c|c|c|c|c|c|c|c|c|}
\hline \multirow{2}{*}{$\begin{array}{c}\text { Root } \\
\text { Extracts }\end{array}$} & \multirow{2}{*}{ Trts } & \multicolumn{4}{|c|}{$\mathrm{pH}$} & \multicolumn{4}{|c|}{ Temp $\left({ }^{\circ} \mathrm{C}\right)$} & \multicolumn{4}{|c|}{$\mathrm{DO}$ (mg/L) } \\
\hline & & $24 \mathrm{hrs}$ & $48 \mathrm{hrs}$ & 72 hrs & $96 \mathrm{hrs}$ & $24 \mathrm{hrs}$ & $48 \mathrm{hrs}$ & $72 \mathrm{hrs}$ & $96 \mathrm{hrs}$ & $24 \mathrm{hrs}$ & $48 \mathrm{hrs}$ & $72 \mathrm{hrs}$ & $96 \mathrm{hrs}$ \\
\hline \multirow{4}{*}{ T. bractiolata } & $0 \mathrm{~g} / 70 \mathrm{~L}$ & $7.2 \pm 0.02^{\mathrm{a}}$ & $\begin{array}{l}7.2 \pm \\
0.01^{\mathrm{a}}\end{array}$ & $\begin{array}{l}7.2 \pm \\
0.02^{\mathrm{a}}\end{array}$ & $\begin{array}{l}7.2 \pm \\
0.02^{\mathrm{a}}\end{array}$ & $\begin{array}{c}27.2 \pm \\
0.02^{\mathrm{a}}\end{array}$ & $\begin{array}{c}27.2 \pm \\
0.02^{\mathrm{a}}\end{array}$ & $\begin{array}{c}27.21 \pm \\
0.00^{\mathrm{a}}\end{array}$ & $\begin{array}{c}27.21 \pm \\
0.01^{\mathrm{a}}\end{array}$ & $\begin{array}{l}5.4 \pm \\
0.01^{a}\end{array}$ & $\begin{array}{l}5.2 \pm \\
0.00^{\mathrm{a}}\end{array}$ & $\begin{array}{l}5.2 \pm \\
0.03^{a}\end{array}$ & $\begin{array}{l}5.3 \pm \\
0.01^{\mathrm{a}}\end{array}$ \\
\hline & $6 \mathrm{~g} / 70 \mathrm{~L}$ & $\begin{array}{c}7.20 .0 \pm \\
0.01^{\mathrm{a}}\end{array}$ & $\begin{array}{l}6.7 \pm \\
0.03^{a}\end{array}$ & $\begin{array}{c}6.42 \pm \\
0.01^{\mathrm{b}}\end{array}$ & $\begin{array}{c}6.42 \pm \\
0.01^{b}\end{array}$ & $\begin{array}{c}27.22 \pm \\
0.01^{\mathrm{a}}\end{array}$ & $\begin{array}{c}25.15 \pm \\
0.01^{\mathrm{b}}\end{array}$ & $\begin{array}{c}26.07 \pm \\
0.03^{\mathrm{a}}\end{array}$ & $\begin{array}{c}26.07 \pm \\
0.02^{\mathrm{a}}\end{array}$ & $\begin{array}{l}5.4 \pm \\
0.02^{\mathrm{a}}\end{array}$ & $\begin{array}{c}5.28 \pm \\
0.02^{\mathrm{b}}\end{array}$ & $\begin{array}{c}5.56 \pm \\
0.03^{a}\end{array}$ & $\begin{array}{c}5.56 \pm \\
0.03^{a}\end{array}$ \\
\hline & $8 \mathrm{~g} / 70 \mathrm{~L}$ & $7.2 \pm 0.02^{\mathrm{a}}$ & $\begin{array}{l}6.3 \pm \\
0.02^{\mathrm{a}}\end{array}$ & $\begin{array}{l}7.1 \pm \\
0.03^{\mathrm{a}}\end{array}$ & $\begin{array}{l}7.1 \pm \\
0.03^{a}\end{array}$ & $\begin{array}{c}27.3 \pm \\
0.03^{a}\end{array}$ & $\begin{array}{c}26.73 \pm \\
0.03^{\mathrm{a}}\end{array}$ & $\begin{array}{c}26.68 \pm \\
0.01^{\mathrm{a}}\end{array}$ & $\begin{array}{c}26.68 \pm \\
0.01^{\mathrm{a}}\end{array}$ & $\begin{array}{c}4.42 \pm \\
0.03^{b}\end{array}$ & $\begin{array}{l}4.5 \pm \\
0.00^{\mathrm{b}}\end{array}$ & $\begin{array}{l}4.5 \pm \\
0.03^{b}\end{array}$ & $\begin{array}{l}4.5 \pm \\
0.00^{\mathrm{b}}\end{array}$ \\
\hline & $10 \mathrm{~g} / 70 \mathrm{~L}$ & $7.3 \pm 0.03^{a}$ & $\begin{array}{c}6.32 \pm \\
0.03^{\mathrm{a}}\end{array}$ & $\begin{array}{l}6.7 \pm \\
0.00^{\mathrm{a}}\end{array}$ & $\begin{array}{l}6.7 \pm \\
0.00^{\mathrm{a}}\end{array}$ & $\begin{array}{c}27.2 \pm \\
0.04^{\mathrm{a}}\end{array}$ & $\begin{array}{c}25.11 \pm \\
0.02^{\mathrm{b}}\end{array}$ & $26 \pm 0.02^{a}$ & $26 \pm 0.00^{a}$ & $\begin{array}{l}4.37 \pm \\
0.02^{b}\end{array}$ & $\begin{array}{c}3.99 \pm \\
0.02^{\mathrm{c}}\end{array}$ & $\begin{array}{c}3.03 \pm \\
0.03^{c}\end{array}$ & $\begin{array}{c}3.03 \pm \\
0.02^{c}\end{array}$ \\
\hline \multirow{3}{*}{ L. sericeus } & $20 \mathrm{~g} / 70 \mathrm{~L}$ & $7.3 \pm 0.01^{\mathrm{a}}$ & $\begin{array}{c}6.15 \pm \\
0.01^{\mathrm{b}}\end{array}$ & $\begin{array}{l}5.7 \pm \\
0.01^{b}\end{array}$ & $\begin{array}{l}5.7 \pm \\
0.01^{b}\end{array}$ & $\begin{array}{c}27.22 \pm \\
0.01^{\mathrm{a}}\end{array}$ & $\begin{array}{c}25.75 \pm \\
0.01^{\mathrm{b}}\end{array}$ & $\begin{array}{c}26.07 \pm \\
0.01^{\mathrm{a}}\end{array}$ & $\begin{array}{c}26.07 \pm \\
0.02^{\mathrm{a}}\end{array}$ & $\begin{array}{l}5.4 \pm \\
0.02^{\mathrm{a}}\end{array}$ & $\begin{array}{c}3.28 \pm \\
0.02^{c}\end{array}$ & $\begin{array}{c}3.56 \pm \\
0.03^{c}\end{array}$ & $\begin{array}{c}3.56 \pm \\
0.05^{c}\end{array}$ \\
\hline & $30 \mathrm{~g} / 70 \mathrm{~L}$ & $7.20 \pm 0.06^{a}$ & $\begin{array}{c}5.63 \pm \\
0.02^{\mathrm{b}}\end{array}$ & $\begin{array}{l}5.1 \pm \\
0.06^{c}\end{array}$ & $\begin{array}{l}5.1 \pm \\
0.06^{c}\end{array}$ & $\begin{array}{c}27.3 \pm \\
0.03^{a}\end{array}$ & $\begin{array}{c}24.33 \pm \\
0.01^{\circ}\end{array}$ & $\begin{array}{c}24.43 \pm \\
0.00^{\mathrm{b}}\end{array}$ & $\begin{array}{c}24.43 \pm \\
0.01^{\mathrm{b}}\end{array}$ & $\begin{array}{c}4.42 \pm \\
0.01^{\mathrm{b}}\end{array}$ & $\begin{array}{l}3.5 \pm \\
0.01^{c}\end{array}$ & $\begin{array}{l}3.5 \pm \\
0.03^{c}\end{array}$ & $\begin{array}{l}3.5 \pm \\
0.01^{c}\end{array}$ \\
\hline & $35 \mathrm{~g} / 70 \mathrm{~L}$ & $7.3 \pm 0.04^{a}$ & $\begin{array}{c}5.42 \pm \\
0.01^{b}\end{array}$ & $\begin{array}{l}5.2 \pm \\
0.05^{c}\end{array}$ & $\begin{array}{l}5.2 \pm \\
0.05^{c}\end{array}$ & $\begin{array}{c}27.2 \pm \\
0.04^{a}\end{array}$ & $\begin{array}{c}24.11 \pm \\
0.00^{c}\end{array}$ & $\begin{array}{c}24.27 \pm \\
0.00^{\mathrm{b}}\end{array}$ & $\begin{array}{c}24.27 \pm \\
0.02^{\mathrm{b}}\end{array}$ & $\begin{array}{c}4.37 \pm \\
0.01^{b}\end{array}$ & $\begin{array}{c}2.99 \pm \\
0.01^{\mathrm{c}}\end{array}$ & $\begin{array}{l}3.03 \pm \\
0.03^{c}\end{array}$ & $\begin{array}{l}3.03 \pm \\
0.02^{c}\end{array}$ \\
\hline
\end{tabular}

Means with the same superscript along the vertical columns are not significantly different $(P>0.05)$.

Table 6: Mean values of water quality parameters containing fish fry and plant extracts within 96 hrs after termination of experiment.

on aquatic organisms, normal behavior was observed in the control treatment. The effect of varying concentrations and exposure time of the two rotenone- yielding plant extracts on test organisms are presented in Tables 5 and 6 below. All the aquatic organisms showed sensitivity 
to rotenone extracts, but some were more resistant to the chemical than others, especially at higher dosage $[23,24]$. Low swimming performance and early mortality were observed in aquaria tanks containing Tadpoles as they clustered together at the surface of water for the two extracts. Young crabs and Water tigers proved to be more resistant to the two plant extracts. Though, T. bractiolata achieved total eradication of Crabs and water tigers at 96 hours of $10 \mathrm{~g} / \mathrm{L}$ concentration. As concentrations of T. bractiolata increased, Nymph of dragon fly recorded progressive number of mortality. On the other hand, $L$. sericeus produced higher mortality tending towards the $96^{\text {th }}$ hour for all the organisms. The rate of mortality of Water tiger and Nymph of dragon fly was highest in test concentrations of $30-35 \mathrm{~g} / \mathrm{L}$ for $L$. sericeus between 72-96 hours, while resistance of young crabs reduced drastically $[25,26]$, a result similar to T. bractiolata concentration at $10 \mathrm{~g} / \mathrm{L}$ between $72-96$ hours exposure.

\section{Discussion}

It was observed that the higher the concentration of the toxicant (rotenone extracts), the higher the mortality rate. This was in line with the observation of Vlawing [3] that in all toxicant, a threshold reach above which there is no drastic survival of animal. Below the threshold, animal is in a tolerance zone. Consequently, it was duly observed from test results that the potency of each test concentrations reduced drastically with the time of exposure. Hence, the peak of potency of Lonchocarpus sericeus was between 48 hours to 72 hours during which a high number of test organisms were lost. The peak of potency in Tephrosia bractiolata was achieved at $10 \mathrm{~g}$, though it produced effects at lower doses of concentrations. Although high, mortality was recorded between 24 to 72 hours in Lonchocarpus sericeus, it was achieved at much higher concentrations [27]. Thus, since Tephrosia bractiolata achieved nearly the same effect as observed in Lonchocapus sericeus but at lower doses, Tephrosia bractiolata is considered to be more potent.

Furthermore, increase in the test concentrations of both extracts shows that the extracts are insoluble in water. Since the concentrations of Lonchocarpus sericeus were increased to have desired effects on test organisms, the insolubility also increased.

Nevertheless, this study has shown that Rotenone extracts are also toxic to fish fry. The range doses that result in toxic effects varies widely with concentration and with the individual species being exposed [28]. Introduction of test concentrations brought about changes in behavior. The effect of the rotenone extracts showed that rotenone causes disruption in gaseous exchange efficiency of the gills and this is similar to the observation of Rahman et al. [29] and Omitoyin [30] change in chemical properties thereof may be reflected in the organisms' respiratory activity particularly if the environmental factors affect respiratory gaseous exchange. In the study of the dissolve oxygen, the treatments did not only show a dose-dependent decline in survival of test organisms but rapid decline in the depletion of oxygen with time. Holden [31] had earlier reported that the introduction of toxicant (pesticide) into aquatic system might decrease dissolved oxygen.

This study has shown that rotenone is toxic to fish as well as other test organisms. It has also proved that the toxicity of the plant extracts varies with the duration of exposure. Prior investigations have shown that pesticide at higher doses in the aquatic environment can accumulate in the tissues of fish as well as other aquatic organisms, thereby disrupting physiological processes. It is however incorrect to deduce that many organisms are unstable in water [31]. Since the crabs are more resistant in water, the concentration can be increased in practical evaluation in earthen fish ponds but Tephrosia bractiolata should be employed [32].
However, the adoption of either of the extracts used in this study in practical terms depends on the resistance of the organisms to be evaluated. Mild doses of the less potent can be used as determined by the fish farmer especially where production cannot be delayed further. Hence, understanding mechanisms of body defense system against Rotenone extracts would enable the farmer in determining the extract and dose to be used [33]. In cases where Lonchocarpus sericeus is used, consistent flow through should be done for a period of weeks before stocking. Fish farmers should use more of Tephrosia bractiolata in eradicating predators as it tends to yield desired results with less residual effects on fish fry.

\section{Conclusion}

Plant root extracts have been widely used to kill predatory aquatic organisms under laboratory rather than natural water bodies. Detailed knowledge of the residual effects on non- target organisms such as fish have not been seriously document under natural water conditions. Therefore, Fisheries managers must apply rotenone yielding plant extracts in natural water bodies in such a measure that only the target organisms are eliminated with no residual effect on fish.

\section{References}

1. Ernest $H$ (2010) A textbook of modern toxicology. John Wiley and Sons

2. Helfrich LA, Wigmann DL, Hipkins $P$ (1996) Pesticides and aquatic animals: A guide to reducing impacts on aquatic systems. Virginia.

3. Robertson DR, Smita V, William F (2008) Rotenone, An essential but demonized tools for assessing marine fish diversity.

4. Fang N, Casida J (1999) Cube resin insecticide: Identification and biological activity of 29 Rotenoid constituents.

5. Anoop KR, Sundar KSG, Khan BA, La S (2009) Common moorhen Gaulinula chloropus in the diet of the African catfish Clarias gariepinus in Keoladeo Ghana National Park, India. Indian Birds 5: 22-23.

6. Arnold N, Ovenden D (2002) Reptiles and Amplibians of Europe. Harper Collins Publishers.

7. Briggs SA (1996) Basic guides to pesticides: Their characteristic and hazards. Hemisphere publishing.

8. Budavarari SD (1996) An encyclopedia of chemical drugs and biologicals (12thedn), Whitehouse Station, NJ: Merck Research Laboratories Division of Merck \& Co, USA

9. Calabrese JEM (1991) Pollution of water pesticides and protection of fish parathion. Proc Nat Acad Sci 4613: 382-392.

10. Crump ML (2009) Amphibian diversity and life history. Amphibian Ecology and Conversation. A handbook of techniques.

11. Vlawing VDC (2000) Application of whole effluent toxicity test produce to ambient water quality assessment. Toxicol chemo 19: 42-52.

12. Extension Toxicology Network (Extonet) (1993) Extoxnet pesticide information Notebook on Rotenone.

13. Fox JE, Gulledge J, Engelhaupt B, McLachlan (2007) Pesticides reduce symbiotic efficiency of nitrogen - fixing rhizobia and host plants.

14. Froese R, Daniel P (2011) Clarias gariepinus in fish base. An encyclopedia on diversity of fresh and marine fish resources.

15. Gilden RC, Nuffling K, Scatter B (2010) Pesticides and health risks. J Obstet Gynecol Neonatal Nurs 39: 103-110.

16. Hodgosn PE (1996) Pesticides: An important but underused model for the environmental health sciences. Environmental health perspectives supplements, Academic search premier.

17. International Programme in Chemical Safety (IPCS) (2003) Rotenone - Health and Safety Guide.

18. IPCS, WHO (2007) The World Health Organization. Recommended classification of pesticides by hazard. World Health Organization. 
Citation: Adebayo IA, Akin-Obasola BJ (2016) Toxicity of Rotenone -Yielding Plant Extracts on Fish Fry and Selected Predatory Aquatic Organisms. J Aquac Res Development 7: 443. doi: 10.4172/2155-9546.1000443

Page 5 of 5

19. Jim JHE (1996) Identification manual for water beetles.

20. Micheal LR (1995) Species diversity in space and time. Cambridge University Press.

21. Odiete OW (1999) Environmental physiology of animal and pollution: Biological assessments 8: 220-237.

22. Ottoboni MA (1991) The dose makes the poison: A plain - language guide to toxicology (2ndedn). New York: Van Nostrand Reionhold.

23. Reynolds JD (1997) Florida State University Journal of land use and environmental law.

24. Sammy DE, Grave N, Dean P, Shane TA (2009) A classification of living and fossil genera of decapods crustaceans (PDF). Raffles Bullentin of Zoology.

25. Semple KTD (2004) Defining bioavailability and bio-accessibility of contaminated soil and sediment is complicated.
26. SQUIRT (2008) National Oceanic and Atmospheric Administration squirt.

27. Tsuda TA (1997)Acute toxicity, accumulation and excreation of organophosporus insecticide and their oxidation process in kill fish chemosphere 35: 939-949.

28. United States Food Drug Administration (2006) Poisonous plant database.

29. Rahman MZ (2002) Effect of Diazinon 6DEC on Anabas testudinous, Barbados gonionotus. The ICLARM Quarterly 35: 8-12.

30. Omitoyin BO (2006) Toxicity of Lindane to Clarias gariepinus. World Journal of Zoology 57-63.

31. Holden AV (1995) Environmental pollution by pesticides effects of pesticide on fish. 6: 217-249.

32. World Health Organization (2001) Recommended classification of pesticide by hazard, WHO/PCS/01.4.

33. Wood DM, Alshahaf $\mathrm{H}$ (2005) Fatality after deliberate ingestion of the pesticide rotenone: A case report. 